\title{
African and classical swine fever: similarities, differences and epidemiological consequences
}

Katja Schulz ${ }^{1 *} \mathbb{D}$, Christoph Staubach $^{1}$ and Sandra Blome ${ }^{2}$

\begin{abstract}
For the global pig industry, classical (CSF) and African swine fever (ASF) outbreaks are a constantly feared threat. Except for Sardinia, ASF was eradicated in Europe in the late 1990s, which led to a research focus on CSF because this disease continued to be present. However, ASF remerged in eastern Europe in 2007 and the interest in the disease, its control and epidemiology increased tremendously. The similar names and the same susceptible species suggest a similarity of the two viral diseases, a related biological behaviour and, correspondingly, similar epidemiological features. However, there are several essential differences between both diseases, which need to be considered for the design of control or preventive measures. In the present review, we aimed to collate differences and similarities of the two diseases that impact epidemiology and thus the necessary control actions. Our objective was to discuss critically, if and to which extent the current knowledge can be transferred from one disease to the other and where new findings should lead to a critical review of measures relating to the prevention, control and surveillance of ASF and CSF. Another intention was to identify research gaps, which need to be closed to increase the chances of a successful eradication of ASF and therefore for a decrease of the economic threat for pig holdings and the international trade.
\end{abstract}

\section{Table of Contents}

1 Introduction

2 Virus

\subsection{ASF}

2.1.1 Virus taxonomy and morphology

2.1.2 Clinical signs and pathology

2.1.3 Immune response and vaccination

2.2 CSF

2.2.1 Virus taxonomy and morphology

2.2.2 Clinical signs and pathology

2.2.3 Immune response and vaccination

3 Epidemiology

3.1 ASF

\subsubsection{Transmission and contagiosity}

3.1.2 Vectors and carriers

3.1.3 Tenacity

3.2 CSF

3.2.1 Transmission and contagiosity

3.2.2 Vectors and carriers

3.2.3 Tenacity

4 History and today's distribution

4.1 ASF

4.2 CSF

5 Prevention and control measures

5.1 ASF

5.2 CSF

6 Conclusions

6.1 Epidemiologically relevant facts concerning CSF

6.2 Epidemiologically relevant facts concerning ASF
${ }^{*}$ Correspondence: katja.schulz@fli.de
1 Friedrich-Loeffler-Institut, Federal Research Institute for Animal Health, Institute of Epidemiology, Südufer 10, 17493 Greifswald, Insel Riems, Germany

Full list of author information is available at the end of the article 


\section{Introduction}

Similar names suggest similar disease characteristics for African and classical swine fever (ASF and CSF). In fact, ASF was even thought to be caused by the same virus as CSF [1] before Montgomery [2] described it as an independent disease entity in Kenya. Yet, despite the similar clinical signs and some shared pathogenic characteristics, the two diseases are caused by completely different viruses $[1,3,4]$.

Nonetheless, both diseases are frequently mentioned at the same time or compared to each other, especially when it comes to epidemiology and disease control. They are both listed by the World Organization for Animal Health (OIE). Diseases found on this list are of considerable international interest and subject to specific regulations [5]. ASF as well as CSF are viral diseases affecting pigs (Suidae) exclusively. In the case of an outbreak, both diseases may generally entail substantial economic consequences for the affected country or region, particularly in western European countries with a considerable pig industry [6-10].

Up to very recently, most central and eastern European countries had mainly experience with CSF, and in many cases, control strategies for ASF were copied from CSF-contingency plans of the past. However, the recent developments of the ASF epidemics in the Baltic EU Member States and in Poland showed that the disease dynamics did not follow the expected pattern and several open questions remain $[11,12]$. The disease neither died out nor spreads with high speed as predicted [13]. So far, the affected countries encounter new cases every week and the situation is out of control in the wild boar population. In this review, our focus was put on similarities and differences of the two viral diseases and the subsequent epidemiological consequences. Due to the particular difficulties to control the diseases in the wild boar population and the constant threat, the presence of the virus in wild boar poses to domestic pig holdings, we focused on the epidemiology in wild boar. By including the latest available scientific findings, this review may help to improve our understanding of the epidemiology of CSF and ASF and thus to optimize prevention and control measures. Furthermore, existing uncertainties were identified and thereby new research can be inspired.

\section{Virus}

\subsection{ASF}

\subsubsection{Virus taxonomy and morphology}

The ASF virus (ASFV) is a large enveloped doublestranded deoxyribonucleic acid (DNA) virus and the only DNA arbovirus (arthropod borne) known so far. The virus belongs to the Asfarviridae family; genus Asfivirus [14]. The genome consists of a linear double-stranded DNA molecule of 170-190 kbp with terminal inverted repetitions and hairpin loops [15]. The viral genome codes for more than 50 structural proteins and several non-structural proteins. ASFV molecular polymorphism has been investigated by partial sequencing of the gene encoding the major capsid protein p72, and 22 distinct genotypes were defined [16]. Recently, an additional genotype was described by Gallardo et al. [17]. Additional sequence information is gathered through partial sequencing of the B602L gene (CVR) or the gene encoding $\mathrm{p} 54$. The virus strains involved in the current eastern European outbreaks belong to genotype II and are highly identical. They show so far only very minor differences. The virus strains circulating on Sardinia are of genotype I and also showed only minor variability, even after decades. In the study of Fraczyk et al. [18], they identified genetic variability within genes related to evasion of host immune system. According to Fraczyk et al. [18] this could help tracing the direction of ASFV isolates molecular evolution. However, studies, identifying further new genetic markers are clearly needed that allow higher resolution molecular epidemiology and thus outbreak tracing.

Table 1 Characteristics of the four manifestations of an infection with the African swine fever virus

\begin{tabular}{|c|c|c|c|c|}
\hline & Peracute form & Acute form & Subacute form & Chronic form \\
\hline Virulence & High & High/moderate & Moderate & Low \\
\hline Clinical signs & $\begin{array}{l}\text { High fever, appetite loss, } \\
\text { lethargy, hyperpnoe }\end{array}$ & $\begin{array}{l}\text { High fever, appetite loss, } \\
\text { lethargy, gastro-intestinal signs }\end{array}$ & $\begin{array}{l}\text { See acute form but less } \\
\text { pronounced }\end{array}$ & Respiratory signs, lameness \\
\hline Pathology & Erythema & $\begin{array}{l}\text { Erythema, petechial haemorrhages } \\
\text { in several organs, lung oedema, } \\
\text { abortion }\end{array}$ & $\begin{array}{l}\text { Erythema, petechial haem- } \\
\text { orrhages in several organs, } \\
\text { haemorrhagic lymph } \\
\text { nodes, abortion }\end{array}$ & $\begin{array}{l}\text { Arthritis, necrotic skin, pneu- } \\
\text { monia, pericarditis, abortion }\end{array}$ \\
\hline Mortality & High & High & Variable & Low \\
\hline
\end{tabular}

Partly adapted from Sanchez-Vizcaino et al. [20] 


\subsubsection{Clinical signs and pathology}

The occurrence and the manifestation of clinical signs depend on different factors. Decisive factors can for example be the virulence of the virus strain, the infection route and dose and the constitution of the affected animal. The incubation period is described to be 2-7 days [19]. According to Sanchez-Vizcaino et al. [20] it can be 5-15 days. Peracute, acute, subacute and chronic form of disease can be distinguished [20]. The ASFV strains causing the outbreaks in eastern Europe are highly virulent and the clinical courses are usually acute and lethal [17, 21 . Experimentally infected wild boar showed also a very high mortality, independently of sex or age [21, 22]. This does not preclude very unspecific courses that can almost go unnoticed. Some characteristics of the different disease forms are outlined in Table 1.

As described in Table 1, mortality may vary according to the virulence of the ASF virus. Infections with high virulent virus strains usually lead to $90-100 \%$ mortality.

\subsubsection{Immune response and vaccination}

Pigs recovering from ASFV infection are usually protected against homologues challenge, but cross-protection against heterologous strains is often missing. Generally, the existence of an antibody-mediated protection, i.e. virus neutralization, is controversially discussed. It is possible to confer a certain level of protection by passive transfer of hyperimmune sera [23]. However, several authors suggest the complete absence of neutralizing antibodies [24], others found that antibodies could reduce virus titers or neutralize ASF virus to a certain extent in vitro [25-27].

It has been reported that animals surviving ASF can become long-term carriers $[28,29]$. This may have a tremendous impact in wild boar populations. So far, it is not clear how many of the survivors may act as carriers and how long they remain infectious. Evidence exists indicating that at least not all animals become long-term carriers [30].

While the role of antibodies is controversially discussed, cytotoxic T-cell responses seem to play a major role in mediating antiviral protection. It was demonstrated that depletion of CD8+ cells leads to abrogation of protection [31].

Safe and efficacious vaccines against ASF do so far not exist, although several approaches have been pursued to develop immunization protocols [32]. Thus, a control strategy in both domestic pigs and wild boar has to rely on veterinary hygiene.

\subsection{CSF}

\subsubsection{Virus taxonomy and morphology}

The agent causing CSF is a small, positive singlestranded, enveloped RNA virus. The CSF virus (CSFV) belongs to the genus Pestivirus within the Flaviviridae family [33]. The genome consists of approximately $12.3 \mathrm{~kb}$ and includes one large open reading frame (ORF) flanked by two non-translated regions (NTRs) [34-36]. The viral genome codes for eleven viral proteins, four structural and seven non-structural (NS) proteins. In detail, the core $(\mathrm{C})$ protein along with three envelope glycoproteins (E1, E2, and Erns) constitutes the virion, and Npro, p7, NS2-3, NS4A, NS4B, NS5A, and NS5B are NS proteins $[37,38]$.

CSFV strains can be assigned to three distinct genotypes with three to four subtypes [39-41]. This classification is based on the nucleotide sequences of fragments of the $5^{\prime}$-non-translated region $\left(5^{\prime}\right.$-NTR), and of the region encoding the glycoprotein E2 [39, 42]. Different subtypes show a particular geographical distribution and genetic typing is used to understand both gross and molecular epidemiology [39, 43, 44]. Recent European strains belong to genotype 2, especially subtypes 2.1 and 2.3 . Most often, these virus strains are moderately virulent.

\subsubsection{Clinical signs and pathology}

Also for CSF, the course of disease depends on several factors like viral virulence, virus dose, health status and particularly the age of the affected animal. Three different courses of infection are known, namely the acute, chronic and prenatal form. The latter can lead to the so called "late onset" form $[7,45]$. The incubation period is in the range of 4-10 days. The acute form of CSF manifests often in fever, respiratory and gastro-intestinal signs, lethargy, and inappetence. The acute lethal form can be accompanied by severe hemorrhagic or neurological signs. Mortality in piglets can be very high, whereas older animals can withstand an infection and develop a life-long immunity [46].

The chronic form is caused by viruses with a lower virulence and usually effects unspecific symptoms like runting, secondary infections of both respiratory and gastro-intestinal tract, skin lesions, and, in the case of sows, reduced fertility. Sometimes, animals can show an initial recovery, however after several months all animals succumb to infection and die. During the whole time of infection, the affected animals shed large amounts of virus $[46,47]$. This course can play an important role in the maintenance of virus transmission.

The outcome of transplacental infection depends on the stage of gestation. In early pregnancy, CSFV infection usually causes abortion, still birth, mummification or malformation [47]. However, infections in the 2nd and 3rd month of pregnancy may lead to the development of persistently infected piglets. These piglets are immunotolerant towards the causative virus strain and may be born healthy. However, they usually runt and develop the 
so-called late onset form of CSF. Also, these animals constantly shed virus until they eventually die $[45,47,48]$.

Regarding the pathology of acute forms, lymph nodes, spleen and kidneys as well as other organs may be edematous and hemorrhagic. Moreover, spleen infarctions and necrotic regions in the tonsils are sometimes found. In animals dying due to the chronic form of CSF, the typical hemorrhages are usually missing, while necrotic lesions in the gastrointestinal tract are more common [47]. Secondary infections may dominate the pathological lesions. The same is true for the late-onset form [49].

\subsubsection{Immune response and vaccination}

Protection against CSFV upon vaccination or an overcome infection is mediated by both humoral and cellular immune responses. Animals that have recovered from field virus infection and animals vaccinated with a conventional live-attenuated vaccine develop antibodies against the structural proteins E2 and Erns as well as the non-structural protein NS3 [50-52]. Especially the E2 antibodies are able to neutralize CSFV and antibody titers can be determined using cell culture-based neutralization assays [53]. Measurable titers are usually found between days 14 and 21 post infection and persist probably lifelong. Moreover, antibodies are transferred by immune sows to their offspring via colostrum. These antibodies have a half-life of roughly 12-14 days and are able to passively protect suckling piglets for a couple of weeks [54]. Beside humoral responses, cell-mediated immunity plays an important role in early protection upon vaccination and in beneficial immune responses upon field virus infection.

Safe and efficacious vaccines exist for both intramuscular vaccination of domestic pigs and oral vaccination of wild boar [55]. The latter have proven that they can be an important tool for CSF eradication from affected wild boar populations [56].

\section{Epidemiology}

\subsection{ASF}

\subsubsection{Transmission and contagiosity}

Three main transmission cycles are described for ASF [57]. A distinction is made between the sylvatic cycle, the tick-pig cycle, and the domestic cycle. The sylvatic cycle refers to the circulation between the African wild suid population and soft ticks. This cycle can be seen in African countries where ASF and ticks of the genus Ornithodoros are endemic. The tick-pig cycle is present in Africa and played a role on the Iberian Peninsula, where ticks infested pig pens and shelters. In the domestic cycle, direct or indirect transmission occurs between domestic pigs. The same applies to transmission among wild boar in the sylvatic cycle in eastern Europe [57, 58]. Direct contact between infected and susceptible animals is a very effective transmission route, but still depending on the virulence of the virus $[28,59]$. Indirect transmission is described through people, vehicles etc. [60]. Although officially banned in most European countries, feeding contaminated meat products or fodder to wild boar or domestic pigs is assumed to play a considerable role in the transmission of ASF [61]. The introduction of the ASF virus from Africa to Portugal in 1957 as well as the introduction into Georgia in 2007 happened most likely through swill feeding of waste from ships at international harbors [62]. ASF virus could be found in boar semen, therefore a transmission through sexual contact or artificial insemination cannot be ruled out [63]. According to Penrith and Vosloo [64] there is no evidence for intrauterine transmission. This is in line with our own unpublished observations.

Ferreira et al. [65] detected viral DNA in air samples and showed a significant association between the detection of virus in feces and in air samples. However, due to the high virus load needed, airborne transmission is not thought to be a major transmission route for ASFV.

Infected animals excrete virus through body fluids like blood, nasal fluid and through feces and urine. However, the amount of virus differs in different fluids. Several studies demonstrated a considerable virus burden in the blood of infected animals, while it was considerably lower in nasal or rectal fluids $[22,58,66]$. Accordingly, contact to infectious blood appears to be the most effective transmission route for ASF [19]. Also, Depner et al. [13] hypothesized that due to the necessary direct contact, the contagiosity of ASF is lower than previously assumed. Results of experimental and field studies support this hypothesis [22, 67]. Following infection studies, the oral infectious dose can vary between 10000 and $18000 \mathrm{TCID}_{50}$ (50\% tissue culture infective dose) [68].

Virus transmission can be described by the basic reproductive number $\left(R_{0}\right)$, which defines the number of secondary infected animals that result from one infected animal. Existing data about the $R_{0}$ value for different ASF virus strains varies considerably in different studies, ranking from 0.5 to 18.0. However, independently of the virus strain, $R_{0}$ was generally lower when transmission happened only through indirect contact $[22,58,59]$.

\subsubsection{Vectors and carriers}

In addition to domestic pigs, wild suids play an important role in the transmission pathways of ASF. In Africa, especially warthogs and bush pigs are known as an asymptomatic reservoir for ASFV [60]. Transmission between warthogs has not been described so far: the presence of soft ticks is therefore believed to be necessary for the spread of the disease [69]. The epidemiological role of 
other African wild suids such as giant forest hogs in the distribution of ASF has not been conclusively evaluated [57]. Many studies demonstrated that the European wild boar is as susceptible to ASF as domestic pigs and can thus act as reservoir under European conditions [69].

As described further above, ASFV is an arbovirus that can replicate in soft ticks. In areas, where ticks of the Ornithodoros genus are endemic, they can play an important role in the transmission of the ASFV $[57,58]$. There is no indication that birds or rodents from infected farms contracted ASF [58]. These findings could be confirmed by Penrith and Vosloo [64]. Mellor et al. [70] could experimentally transmit ASFV from Stomoxys flies to pigs. For central Europe, there is no evidence that soft ticks could play a role [71]. There is no evidence that Ornithodoros spp. occur in this region. Moreover, hard ticks do not seem to play a role either [72].

\subsubsection{Tenacity}

It is known that the survival time of the virus can be up to 18 months in serum at room temperature. However, the survival time decreases with increasing temperature and can be longer in frozen material. The virus is stable across a wide range of $\mathrm{pH}$-levels; it can resist a $\mathrm{pH}$ level between 4 and 13 [73]. Several studies demonstrated that ASFV can stay infective in raw ham or sausage but also in treated meat products for several months. However, it was also shown, that cooking meat kills the virus within few minutes, whereas it can stay infectious at least 1000 days in frozen meat [74-76].

\subsection{CSF}

\subsubsection{Transmission and contagiosity}

Virus can be excreted through feces and all body fluids like saliva and urine. Infected animals may excrete large amounts of virus over a relatively long period [77]. Infection usually happens oro-nasally often through direct but potentially also through indirect contact $[7,78,79]$. The infectious dose through oro-nasal infection ranges between $10 \mathrm{TCID}_{50}$ and $80 \mathrm{TCID}_{50}$ [65]. Different indirect transmission routes are described. Indirect contact to wild boar, for example through contact to contaminated hunting material or vehicles could be identified as an important source for virus introduction into commercial pig holdings $[80,81]$. Also, indirect transmission through infected feed or garbage (illegal swill feeding) has been suggested as a common source for virus introduction into a naïve population $[7,80]$. Movements of persons entail the risk of transmission through contaminated clothes, vehicles or repeatedly used needles [8284]. Indirect transmission via excretions are described to be rather unlikely [85].
The CSFV is able to cross the placental barrier and consequently to infect fetuses in the uterus $[45,86]$. Virus transmission through boar semen has also been reported [87-89]. Transmission via air was suspected in farms where secondary outbreaks without any detectable direct or indirect contact to the originally affected farm have occurred [82]. Potential virus transmission via air could be documented under experimental conditions $[15,90$, 91]. Weesendorp et al. [92] and Weesendorp et al. [93] detected CSF virus in a pen where infected pigs had been housed. However, Weesendorp et al. [91] showed that the transmission rate was significantly higher among pigs housed in the same pen then between pigs housed in different pens or via air, which emphasizes the importance of the transmission routes mentioned above.

The $R_{0}$ value for CSF virus depends on the number of susceptible animals, on the population density and also on the virulence of the CSF virus [7, 45, 94]. Several studies determined a high $\mathrm{R}_{0}$ values for within-herd transmission, indicating a high contagiosity when direct contact between the animals is possible [86, 95, 96]. However, Weesendorp et al. [94] showed that direct transmission is highly dependent on the virulence of the virus strain. They found that pigs that had direct contact with animals infected with a low virulent strain did not get infected.

Besides the direct relationship between population density and the $R_{0}$, a reduced number of highly susceptible young pigs decreases the chance of disease persistence in a population [7, 97-99]. Stegeman et al. [100] found that the transmission of CSF virus among breeding pigs was clearly lower with a $R_{0}$ of 2.9 than in herds of weaned piglets and slaughter pigs.

\subsubsection{Vectors and carriers}

Although the role of various animal species as potential vectors for CSF has been intensively studied, transmission seems to occur mainly if not exclusively between pigs. Neither arthropods nor rodents or birds could be reliably identified as vectors for the virus [82, 101, 102]. Wild boar constitute an important carrier of CSFV and therefore pose a constant risk to introduce the virus into pig farms [7, 80]. Everett et al. [103] showed in their study that warthogs as well as bushpigs can be infected with CSF virus and can also transmit the disease.

\subsubsection{Tenacity}

Similar to ASFV, the tenacity of CSFV in the environment depends on a number of factors. Several studies could demonstrate a relationship between ambient temperature and the tenacity of the virus [77, 104-107]. Accordingly, the period of time, the virus remains infectious, decreases with increasing temperature. In the study 
of Weesendorp et al. [104] it was calculated that virus would remain infectious for a few days in feces and urine at $22{ }^{\circ} \mathrm{C}$. However, at $5{ }^{\circ} \mathrm{C}$ infectious virus would remain detectable for several weeks. Botner and Belsham [108] could show that the tenacity of CSF virus in slurry was short when it was heated, but the virus remained infectious for weeks at cool temperatures.

Farez and Morley [107] describe in their study a tenacity of years in meat frozen at $-70{ }^{\circ} \mathrm{C}$. They also listed time periods, for which the virus stayed infectious in different meat products, illustrating that these periods may range from 40 days to several years, depending on the treatment. Treatments like salt-cures and smoking do not seem to reduce the infectivity of CSF virus significantly, whereas pasteurization and cooking inactivates the virus [105]. Also, the protein concentration in the matrix influences the tenacity of the virus. The higher the protein concentration, the longer stays the CSF virus infectious [77]. Another factor affecting the stability of the virus is the pH-value [105-107, 109]. It was found that virus is inactivated below a $\mathrm{pH}$-level of 4 and above pH 11 [109].

\section{History and today's distribution}

\subsection{ASF}

The first time, when ASF was identified as an independent disease entity, was in Kenya in 1910 [2]. After its first detection, ASF was found to circulate in several African states until it was introduced into Portugal in 1957. After successful eradication in Portugal, the disease was reintroduced in 1960 and spread to several European countries. Before it was finally eradicated in 1995, ASF stayed endemic on the Iberian Peninsula [6, $61,64]$. Since the virus was newly introduced into Sardinia in 1978, ASF has remained endemic in several parts of Sardinia [110]. The disease did not only reach Europe, but also different countries in South and Central America, from where it was successfully eradicated. For many years, ASF could be found endemic only in African states and Sardinia [61]. However, in 2007 ASF was again detected in Europe, namely in Georgia, from where it spread into the neighbor states Armenia, Azerbaijan and the Russian Federation [62, 111]. In 2012 and 2013, also the Ukraine and Belarus reported an ASF outbreak [20]. In 2014, ASF reached the European Union, where outbreaks were confirmed in Lithuania, Latvia, Estonia and Poland [11, 12, 20, 112]. Currently, the virus is still circulating in all four countries with frequent new outbreaks, mainly in wild boar, but occasionally also in domestic pigs (Figure 1). In addition, ASF cases were detected in Moldova for the first time in October 2016 [113].

\subsection{CSF}

The first official reports about the occurrence of CSF virus originate from Ohio, USA, where the disease was first described in 1833. Between 1860 and 1970 the CSF was widely distributed over the American and the European continents [105]. In 1978, CSF was eradicated in North America [109]. Since then, North America and Australia are officially free from CSF [114]. Mainly due to inadequate reporting and lack of surveillance, the disease situation in Africa remains unclear. However, it is known, that CSF has been endemic in parts of Asia as well as in areas of Central and South America since several years [114]. After devastating outbreaks in the Netherlands and in Germany in the late 1990s and sporadic outbreaks that occurred thereafter, the last outbreaks in Europe were reported in domestic pigs from Latvia in 2014. In wild boar, however, the disease was at least present until 2016 in the latter country [115].

\section{Prevention and control measures 5.1 ASF}

Currently, no vaccination for ASF is available. To prevent the introduction of ASF, movement restrictions regarding pigs, pork, blood and other products from pigs kept in affected areas as well as potentially contaminated material, vehicles etc. are in place. Following European Commission [116], necessary biosecurity measures are defined, e.g. swill feeding, in commercial pig farms as well as in wild boars, must be prohibited, especially in high risk areas. Direct or indirect contact to wild boar or to any by products has to be avoided. The measures that have to be taken in a case of ASF suspicion or an actual outbreak in the European Union have been specified by European Commission [117]. When an outbreak of ASF in a farm has been confirmed, all pigs of the premise must be culled. In addition, further measures like the safe disposal of all potentially contaminated material, restriction (minimum radius of $3 \mathrm{~km}$ ) and surveillance (minimum radius of $10 \mathrm{~km}$ ) zones with movement restrictions for pigs and products of porcine origin have to be set up. Specific regulations have been defined for both zones in European Commission [117].

\subsection{CSF}

The prevention and control measures regarding CSF in domestic pigs are very similar to the ones described for ASF. Detailed regulations applying for member states of European Commission [118]. However, in the case of specific epidemiological situations, vaccination can be used to control CSF in domestic pigs. Vaccination of 


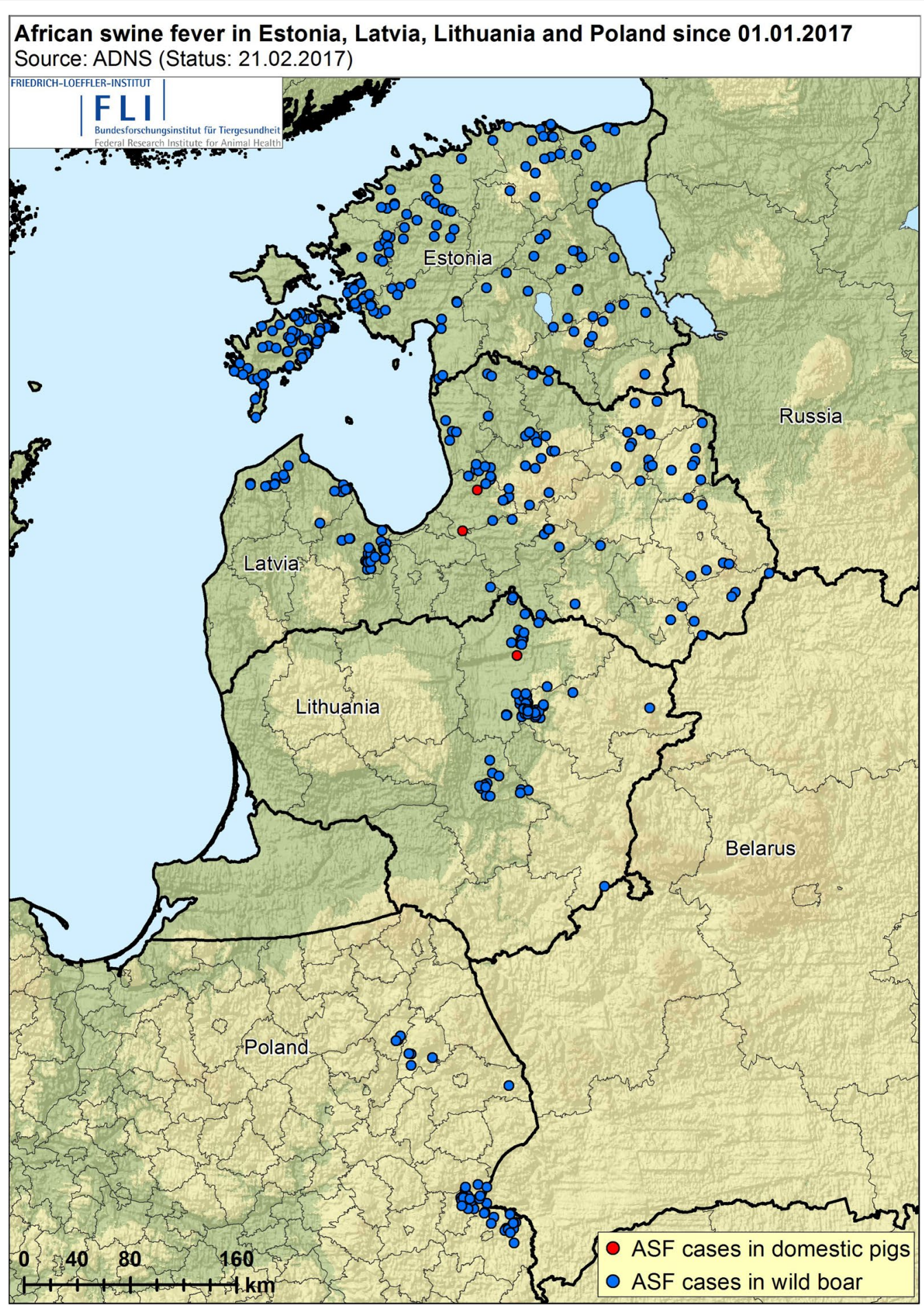

Figure 1 Current distribution of African swine fever cases in domestic pigs and wild boar in the affected countries of the European Union. (Source: ADNS Data, Status 21.2.2017).

wild boar can be also be applied and may represent the method of choice in combination with other elements of surveillance and control [118].

\section{Conclusions}

Following the introduction of ASF into the Trans-Caucasian countries and the Russian Federation in 2007 
and into the European Union in 2014, several countries including Germany sought to set up and update their surveillance and control plans (contingency plans) for the disease.

Especially the countries with previous CSF experience tried to use their CSF contingency plans as a blue print and copied most of the measures that had been found suitable to control CSF.

For the control measures of ASF in wild boar populations, this approach does not seem to be promising as the disease dynamics proved to be too different for the two diseases: Neither self-limitation, which was assumed to occur due to the high virulence of the virus strain circulating in Eastern Europe nor fast spread due to high contagiosity and connected habitats took place [13]. Thus, reconsideration of control and surveillance options is needed.

In this review, we tried to point out major similarities and differences of CSF and ASF with the overall objective to provide background information on disease biology and dynamics that could feed into adapted strategies. Some of the most important similarities/differences are summarized in Table 2.

The similarities mainly concern the range of vertebrate hosts as well as clinical signs and pathomorphological lesions that necessitate swift and reliable diagnostic tools. Both diseases are usually accompanied by a steep increase in mortality when introduced into a naïve population. This gives passive surveillance high impact for the early detection of disease introduction into both domestic pigs and wild boar [119]. With regard to the detection and differentiation of the diseases, molecular tools have been developed and validated that allow both steps in one assay (e.g. [120,121]). Moreover, both routine sample sets and alternative sample matrices work for both diseases with quite similar performance [122].

Another similarity is the quite high tenacity of the causative agents, especially under cold conditions $[74,76$, 105]. Both viruses, ASFV and CSFV, are able to remain infectious for several weeks under adequate climatic conditions (cold environment). Elevated temperatures inactivate both viruses rather quickly. Moreover, both are stable within a wide range of $\mathrm{pH}$-values $[73,109]$.

Apart from these basic features, which could at least lead to combined passive surveillance approaches in disease free areas that are at risk, several differences exist between ASF and CSF that take effect especially when wild boar populations are concerned.

\subsection{Epidemiologically relevant facts concerning CSF}

Recent European CSFV strains have shown moderate virulence and an age-dependence of clinical symptoms. This is important for the target population of active surveillance but also disease dynamics as it can be assumed that older animals will survive [119]. Survivors will be safe as they are protected probably livelong from reinfection. Immune sows will confer protection to young piglets via maternally derived antibodies in the colostrum.

In outbreak regions with moderate to high wild boar density, the seroprevalence often rises very quickly and antibody detection is a most valuable tool to characterize the outbreak extent.

Long-term shedders will most probably be present (chronically infected animals and persistently infected piglets after transplacental transmission), but meet increasing population immunity. Shedding is generally high in all se- and excretions and thus, swift spread is likely within a sounder.

Also, CSF has shown potential to become endemic in wild boar populations rather than dying out. This is probably due to the high wild boar density in affected areas in Europe in combination with the above mentioned low/ moderate virulence. For this virus, this virulence level could be an optimum for long-term maintenance [123]. However, vaccination exists as an additional tool to eradicate CSF from a wild boar population and most probable, even production and application of a DIVA (differentiation of infected from vaccinated animals) vaccine is feasible [58].

\subsection{Epidemiologically relevant facts concerning ASF}

Recent European ASFV strains have shown high virulence [124], almost no age-dependence of clinical symptoms and a high case-fatality ratio [19]. The fate of survivors is still not clear as these animals could act as long-term carriers. In fact, survivors will at least be positive for prolonged periods $[28,125]$. In the later stages of their infection, mobility can be assumed and thus possible increase in infectious contacts. However, there is also evidence that this is not inevitable [30].

In outbreak regions, the seroprevalence is rising steadily but slowly. It often stays below $10 \%$, even in heavily affected areas. Thus, serology is an important tool to understand and investigate disease dynamics but a difficult target for active surveillance (sample sizes that could detect seropositivity with a sufficiently low prevalence threshold and acceptable confidence can hardly be obtained).

Shedding is generally low in most se- and excretions and thus, blood contact is the main source of infection. Even within groups of animals that have close contact, transmission might be slow and some animals may even go uninfected within a highly affected sounder. Yet, due to the high tenacity of the virus in blood, infectiousness can be assumed for long periods and thus, carcasses and 


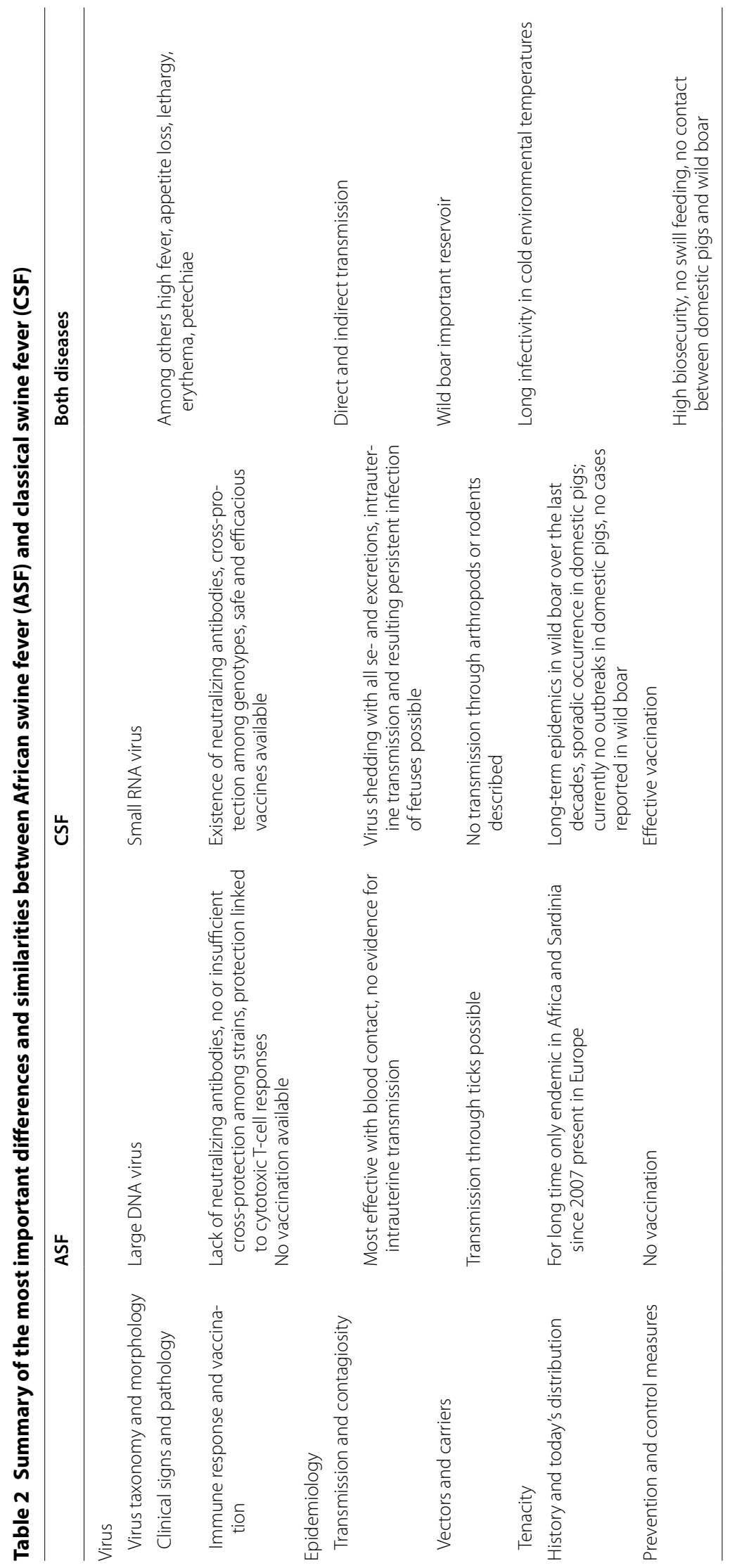


blood contaminated fomites can act as long-term source of infection. Transplacental transmission has not been described for ASF [64].

Little is known about the role of maggots or other insect larvae, the fate of carcasses under different conditions, and environmental factors such as so soil underneath a carcass. It could recently be demonstrated that several of these matrices are positive for ASFV genome, but live virus is probably rare or non-existent.

Although not involved in the current situation in Eastern Europe, soft ticks can play a role in ASF transmission. This may add another player and more complexity to the control scenario. It has been proven that tick involvement can have high impact on outbreak duration.

No vaccine exists that could aid control options. Developing a vaccine for the wild boar population would mean to develop a safe and efficacious oral vaccine. So far, there is no such vaccine at the horizon.

Thus, besides the shared common features, the differences between ASF and CSF clearly dominate and entail more serious epidemiological consequences. With regard to surveillance actions, the focus for CSF on piglets is clearly counterproductive for the current ASF situation. For ASF, herd immunity does not play an important role for a long period of time and thus time does not act necessarily as beneficial factor. CSF and ASF have different levels of contagiosity and thus transmission characteristics, for example, the $\mathrm{R}_{0}$ for ASF is lower than for CSF. However, there is a relatively low number of studies, in which these values were estimated. Moreover, different algorithms, virus strains, diagnostic tools and host characteristics were used, which makes those studies hardly comparable. Nonetheless, experimental as well as field studies refute previous assumptions of a high contagiosity of ASF. Based on the low contagiosity but high tenacity of the virus in carcasses and blood, ASF surveillance has to focus even more on detecting dead individuals to avoid any direct contact and therefore further spread [126].

Regarding ASF, further studies should focus on ASF transmission in the field and on environmental factors, like soil and organisms around wild boar carcasses. Moreover, the role of survivors needs further investigation.

One of the research gaps concerning CSF relates to the final licensing of the available DIVA vaccine. The use of such a vaccine would help to better understand the balance between vaccine induced and natural immunity and thus dynamics of epidemics and their control.

To close these gaps and to deduce appropriate control options, collaboration is needed among research institution of affected and non-affected countries.

\section{Abbreviations}

ASF: African swine fever; CSF: classical swine fever; DNA: deoxyribonucleic acid; RNA: ribonucleic acid; $\mathrm{TCID}_{50}$ : $50 \%$ tissue culture infective dose; $\mathrm{R}_{0}$ : basic reproductive number; DIVA: differentiating infected from vaccinated animals.

\section{Competing interests}

The authors declare that they have no competing interests.

\section{Authors' contributions}

KS planned and drafted the manuscript. CS and SB provided additional information and contributed to writing the manuscript. All authors read and approved the final manuscript.

\section{Acknowledgements}

We want to thank Prof. Dr Franz J. Conraths for assistance in the final editing and the proofreading of the manuscript.

\section{Author details}

${ }^{1}$ Friedrich-Loeffler-Institut, Federal Research Institute for Animal Health, Institute of Epidemiology, Südufer 10, 17493 Greifswald, Insel Riems, Germany. ${ }^{2}$ Friedrich-Loeffler-Institut, Federal Research Institute for Animal Health, Institute of Diagnostic Virology, Südufer 10,17493 Greifswald, Insel Riems, Germany.

\section{Publisher's Note}

Springer Nature remains neutral with regard to jurisdictional claims in published maps and institutional affiliations.

Received: 24 April 2017 Accepted: 8 November 2017

Published online: 28 November 2017

\section{References}

1. Penrith ML (2013) History of 'swine fever' in southern Africa. J S Afr Vet Assoc 84:1106

2. Montgomery RE (1921) On a form of swine fever occurring in British East Africa (Kenya Colony). J Comp Pathol Ther 34:159-191

3. Moennig V (2000) Introduction to classical swine fever: virus, disease and control policy. Vet Microbiol 73:93-102

4. Gomez-Villamandos JC, Carrasco L, Bautista MJ, Sierra MA, Quezada M, Hervas J, De Lara FCM, Ruiz-Villamor E, Salguero FJ, Sonchez-Cordon PJ, Romanini S, Nunez A, Mekonen T, Mendez A, Jover A (2003) African swine fever and classical swine fever: a review of the pathogenesis. Dtsch Tierarztl Wochenschr 110:165-169

5. OIE (2011) Terrestrial animal health code, $12^{\text {th }}$ edn. World Organisation for Animal Health, Paris, $\mathrm{p} 7$

6. Sanchez-Vizcaino JM, Mur L, Martinez-Lopez B (2012) African swine fever: an epidemiological update. Transbound Emerg Dis 59:27-35

7. Moennig V (2015) The control of classical swine fever in wild boar. Front Microbiol 6:1211

8. Chander V, Nandi S, Ravishankar C, Upmanyu V, Verma R (2014) Classical swine fever in pigs: recent developments and future perspectives. Anim Health Res Rev 15:87-101

9. Meuwissen MPM, Horst SH, Huirne RBM, Dijkhuizen AA (1999) A model to estimate the financial consequences of classical swine fever outbreaks: principles and outcomes. Prev Vet Med 42:249-270

10. Gogin A, Gerasimov V, Malogolovkin A, Kolbasov D (2013) African swine fever in the North Caucasus region and the Russian Federation in years 2007-2012. Virus Res 173:198-203

11. Smietanka K, Wozniakowski G, Kozak E, Niemczuk K, Fraczyk M, Bocian L, Kowalczyk A, Pejsak Z (2016) African swine fever epidemic, Poland, 2014-2015. Emerg Infect Dis 22:1201-1207

12. Wozniakowski G, Kozak E, Kowalczyk A, Lyjak M, Pomorska-Mol M, Niemczuk K, Pejsak Z (2016) Current status of African swine fever virus in a population of wild boar in eastern Poland (2014-2015). Arch Virol 161:189-195

13. Depner K, Staubach C, Probst C, Globig A, Blome S, Dietze K, SauterLouis C, Conraths FJ (2016) African swine fever-epidemiological 
considerations and consequences for disease control. Tierarzt Umschau 71:72-78

14. World Organisation for Animal Health (2012) African swine fever. In: OIE (ed) Manual of diagnostic tests and vaccines for terrestrial animals. World Organisation for Animal Health, Paris, pp 1067-1068

15. Gonzalez C, Pijoan C, Ciprian A, Correa P, Mendoza S (2001) The effect of vaccination with the PAV-250 strain classical swine fever (CSF) virus on the airborne transmission of CSF virus. J Vet Med Sci 63:991-996

16. Lubisi BA, Bastos ADS, Dwarka RM, Vosloo W (2005) Molecular epidemiology of African swine fever in East Africa. Arch Virol 150:2439-2452

17. Gallardo C, Fernandez-Pinero J, Pelayo V, Gazaev I, Markowska-Daniel I, Pridotkas G, Nieto R, Fernandez-Pacheco P, Bokhan S, Nevolko O, Drozhzhe Z, Perez C, Soler A, Kolvasov D, Arias M (2014) Genetic variation among African swine fever genotype II viruses, eastern and central Europe. Emerg Infect Dis 20:1544-1547

18. Fraczyk M, Wozniakowski G, Kowalczyk A, Bocian L, Kozak E, Niemczuk K, Pejsak Z (2016) Evolution of African swine fever virus genes related to evasion of host immune response. Vet Microbiol 193:133-144

19. Blome S, Gabriel C, Beer M (2013) Pathogenesis of African swine fever in domestic pigs and European wild boar. Virus Res 173:122-130

20. Sanchez-Vizcaino JM, Mur L, Gomez-Villamandos JC, Carrasco L (2015) An update on the epidemiology and pathology of African swine fever. J Comp Pathol 152:9-21

21. Blome S, Gabriel C, Dietze K, Breithaupt A, Beer M (2012) High virulence of African swine fever virus caucasus isolate in European wild boars of all ages. Emerg Infect Dis 18:708

22. Pietschmann J, Guinat C, Beer M, Pronin V, Tauscher K, Petrov A, Keil G, Blome S (2015) Course and transmission characteristics of oral low-dose infection of domestic pigs and European wild boar with a Caucasian African swine fever virus isolate. Arch Virol 160:1657-1667

23. Onisk DV, Borca MV, Kutish G, Kramer E, Irusta P, Rock DL (1994) Passively transferred African swine fever virus antibodies protect swine against lethal infection. Virology 198:350-354

24. Dimmock NJ (1993) Neutralization of animal viruses. Springer, Berlin

25. Borca MV, Irusta P, Carrillo C, Afonso CL, Burrage T, Rock DL (1994) African swine fever virus structural protein p72 contains a conformational neutralizing epitope. Virology 201:413-418

26. Zsak L, Onisk DV, Afonso CL, Rock DL (1993) Virulent African swine fever virus isolates are neutralized by swine immune serum and by monoclonal antibodies recognizing a 72-kDa viral protein. Virology 196:596-602

27. Escribano JM, Galindo I, Alonso C (2013) Antibody-mediated neutralization of African swine fever virus: myths and facts. Virus Res 173:101-109

28. Gallardo C, Soler A, Nieto R, Sanchez MA, Martins C, Pelayo V, Carrascosa A, Revilla Y, Simon A, Briones V, Sanchez-Vizcaino JM, Arias M (2015) Experimental transmission of African swine fever (ASF) low virulent isolate NH/P68 by surviving pigs. Transbound Emerg Dis 62:612-622

29. Mebus CA, Dardiri AH (1980) Western hemisphere isolates of African swine fever virus: asymptomatic carriers and resistance to challenge inoculation. Am J Vet Res 41:1867-1869

30. Nurmoja I, Petrov A, Breidenstein C, Zani L, Forth JH, Beer M, Kristian M, Viltrop A, Blome S (2017) Biological characterization of African swine fever virus genotype II strains from north-eastern Estonia in European wild boar. Transbound Emerg Dis 64:2034-2041

31. Oura CA, Denyer MS, Takamatsu H, Parkhouse RM (2005) In vivo depletion of CD8+T lymphocytes abrogates protective immunity to African swine fever virus. J Gen Virol 86:2445-2450

32. Rock DL (2017) Challenges for African swine fever vaccine development-"... perhaps the end of the beginning". Vet Microbiol 206:52-58

33. Lindenbach BD, Murray CL, Thiel HJ, Rice CM (2013) Flaviviridae. In: Knipe DM, Howley PM (eds) Fields virology, vol I. Lippincott-Raven, Philadelphia, pp 713-746

34. Collett MS (1992) Molecular genetics of pestiviruses. Comp Immunol Microbiol Infect Dis 15:145-154

35. Thiel HJ, Stark R, Weiland E, Rumenapf T, Meyers G (1991) Hog-cholera virus: molecular composition of virions from a pestivirus. J Virol 65:4705-4712

36. Rümenapf T, Meyers G, Stark R, Thiel HJ (1991) Molecular characterization of hog cholera virus. Arch Virol Suppl 3:7-18

37. Elbers K, Tautz N, Becher P, Stoll D, Rumenapf T, Thiel HJ (1996) Processing in the pestivirus E2-NS2 region: identification of proteins $p 7$ and E2p7. J Virol 70:4131-4135
38. Lattwein E, Klemens O, Schwindt S, Becher P, Tautz N (2012) Pestivirus virion morphogenesis in the absence of uncleaved nonstructural protein 2-3. JVirol 86:427-437

39. Paton DJ, McGoldrick A, Greiser-Wilke I, Parchariyanon S, Song JY, Liou PP, Stadejek T, Lowings JP, Bjorklund H, Belak S (2000) Genetic typing of classical swine fever virus. Vet Microbiol 73:137-157

40. Postel A, Schmeiser S, Bernau J, Meindl-Boehmer A, Pridotkas G, Dirbakova Z, Mojzis M, Becher P (2012) Improved strategy for phylogenetic analysis of classical swine fever virus based on full-length E2 encoding sequences. Vet Res 43:50

41. Postel A, Schmeiser S, Perera CL, Rodriguez LJ, Frias-Lepoureau MT, Becher P (2013) Classical swine fever virus isolates from Cuba form a new subgenotype 1.4. Vet Microbiol 161:334-338

42. Greiser-Wilke I, Dreier S, Haas L, Zimmermann B (2006) Genetic typing of classical swine fever viruses - a review. Dtsch Tierarztl Wochenschr 113:134-138

43. Beer M, Goller KV, Staubach C, Blome S (2015) Genetic variability and distribution of classical swine fever virus. Anim Health Res Rev 16:33-39

44. Depner KR, Strebelow G, Staubach C, Kramer M, Teuffert J, Botcher L, Hoffmann B, Beer M, Greiser-Wilke I, Mettenleiter T (2006) Case report: the significance of genotyping for the epidemiological tracing of classical swine fever (CSF). Dtsch Tierarztl Wochenschr 113:159-162

45. Artois M, Depner KR, Guberti V, Hars J, Rossi S, Rutili D (2002) Classical swine fever (hog cholera) in wild boar in Europe. Rev Sci Tech 21:287-303

46. World Organisation for Animal Health (2009) Classical swine fever (hog cholera). In: Manual of diagnostic tests and vaccines for terrestrial animals. OIE Biological Standards Commission, Paris

47. Moennig V, Floegel-Niesmann G, Greiser-Wilke I (2003) Clinical signs and epidemiology of classical swine fever: a review of new knowledge. Vet J 165:11-20

48. Depner KR, Müller A, Gruber A, Rodriguez A, Bickhardt K, Liess B (1995) Classical swine fever in wild boar (Sus scrofa) —experimental infections and viral persistence. Dsch Tierarztl Wochensch 102:381-384

49. Dahle J, Liess B (1992) A review on classical swine fever infections in pigs: epizootiology, clinical disease and pathology. Comp Immunol Microbiol Infect Dis 15:203-211

50. Wensvoort G, Bloemraad M, Terpstra C (1988) An enzyme immunoassay employing monoclonal antibodies and detecting specifically antibodies to classical swine fever virus. Vet Microbiol 17:129-140

51. König M, Lengsfeld T, Pauly T, Stark R, Thiel HJ (1995) Classical swine fever virus: independent induction of protective immunity by two structural glycoproteins. J Virol 69:6479-6486

52. Paton DJ, Ibata G, Edwards S, Wensvoort G (1991) An ELISA detecting antibody to conserved pestivirus epitopes. J Virol Methods 31:315-324

53. Greiser-Wilke I, Blome S, Moennig V (2007) Diagnostic methods for detection of Classical swine fever virus - status quo and new developments. Vaccine 25:5524-5530

54. Terpstra C, Robijns KG (1977) Experience with regional vaccination against swine fever in enzootic areas for limited periods using C-strain virus. Tijdschr Diergeneesk 102:106-112

55. Blome S, Gabriel C, Beer M (2013) Possibilities and limitations in veterinary vaccine development using the example of classical swine fever. Berl Munch Tierarztl Wochenschr 126:481-490

56. Rossi S, Staubach C, Blome S, Guberti V, Thulke HH, Vos A, Koenen F, Le Potier MF (2015) Controlling of CSFV in European wild boar using oral vaccination: a review. Front Microbiol 6:1141

57. Costard S, Mur L, Lubroth J, Sanchez-Viscaino JM, Pfeffer DU (2013) Epidemiology of African swine fever virus. Virus Res 173:191-197

58. Guinat C, Gogin A, Blome S, Keil G, Pollin R, Pfeiffer DU, Dixon L (2016) Transmission routes of African swine fever virus to domestic pigs: current knowledge and future research directions. Vet Rec 178:262-267

59. Guinat C, Gubbins S, Vergne T, Gonzales IL, Dixon L, Pfeiffer DU (2016) Experimental pig-to-pig transmission dynamics for African swine fever virus, Georgia 2007/1 strain. Epidemiol Infect 144:25-34

60. Wozniakowski G, Fraczyk M, Niemczuk K, Pejsak Z (2016) Selected aspects related to epidemiology, pathogenesis, immunity, and control of African swine fever. J Vet Res 60:119-125

61. Costard S, Wieland B, de Glanville W, Jori F, Rowlands R, Vosloo W, Roger F, Pfeiffer DU, Dixon LK (2009) African swine fever: how can global spread be prevented? Philos Trans R Soc Lond B 364:2683-2696 
62. Rowlands RJ, Michaud V, Heath L, Hutchings G, Oura C, Vosloo W, Dwarka R, Onashvili T, Albina E, Dixon LK (2008) African swine fever virus isolate, Georgia, 2007. Emerg Infect Dis 14:1870-1874

63. Thacker BJ, Larsen RE, Joo HS, Leman AD (1984) Swine diseases transmissible with artificial-insemination. J Am Vet Med Assoc 185:511-516

64. Penrith ML, Vosloo W (2009) Review of African swine fever: transmission, spread and control. J S Afr Vet Assoc 80:58-62

65. Ferreira HCD, Backer JA, Weesendorp E, Klinkenberg D, Stegeman JA, Loeffen WLA (2013) Transmission rate of African swine fever virus under experimental conditions. Vet Microbiol 165:296-304

66. Guinat C, Reis AL, Netherton CL, Goatley L, Pfeiffer DU, Dixon L (2014) Dynamics of African swine fever virus shedding and excretion in domestic pigs infected by intramuscular inoculation and contact transmission. Vet Res 45:93

67. Olsevskis E, Guberti V, Serzants M, Westergaard J, Gallardo C, Rodze I, Depner K (2016) African swine fever virus introduction into the EU in 2014: experience of Latvia. Res Vet Sci 105:28-30

68. McVicar JW (1984) Quantitative aspects of the transmission of African swine fever. Am J Vet Res 45:1535-1541

69. Jori F, Bastos ADS (2009) Role of wild suids in the epidemiology of African swine fever. EcoHealth 6:296-310

70. Mellor PS, Kitching RP, Wilkinson PJ (1987) Mechanical transmission of capripox virus and african swine fever virus by Stomoxys calcitrans. Res Vet Sci 43:109-112

71. Pietschmann J, Mur L, Blome S, Beer M, Perez-Sanchez R, Oleaga A, Sanchez-Vizcaino JM (2016) African swine fever virus transmission cycles in Central Europe: evaluation of wild boar-soft tick contacts through detection of antibodies against Ornithodoros erraticus saliva antigen. BMC Vet Res 12:1

72. de Carvalho Ferreira H, Tudela Zúquete S, Wijnveld M, Weesendorp E, Jongejan F, Stegeman A, Loeffen W (2014) No evidence of African swine fever virus replication in hard ticks. Ticks Tick Borne Dis 5:582-589

73. Mebus C, Arias M, Pineda JM, Tapiador J, House C, Sanchez-Vizcaino JM (1997) Survival of several porcine viruses in different Spanish dry-cured meat products. Food Chem 59:555-559

74. Mebus CA, House C, Gonzalvo FR, Pineda JM, Tapiador J, Pire JJ, Bergada J, Yedloutschnig RJ, Sahu S, Becerra V, Sanchezvizcaino JM (1993) Survival of foot-and-mouth-disease, African swine fever, and hogcholera viruses in Spanish serrano cured hams and Iberian cured hams, shoulders and loins. Food Microbiol 10:133-143

75. European Food And Safety Authority (2010) Scientific opinion on African swine fever. EFSA J 8:11-13

76. McKercher PD, Yedloutschnig RJ, Callis JJ, Murphy R, Panina GF, Civardi A, Bugnetti M, Foni E, Laddomada A, Scarano C, Scatozza F (1987) Survival viruses in prosciutto-di-parma (parma ham). Can Inst Food Sci Technol J 20:267-272

77. Blome S, Gabriel C, Beer M (2012) Viral diseases in pigs: classical swine fever. Prakt Tierarzt 93:18-20

78. Paton DJ, Greiser-Wilke I (2003) Classical swine fever-an update. Res Vet Sci 75:169-178

79. Penrith ML, Vosloo W, Mather C (2011) Classical swine fever (hog cholera): review of aspects relevant to control. Transbound Emerg Dis 58:187-196

80. Fritzemeier J, Teuffert J, Greiser-Wilke I, Staubach C, Schluter H, Moennig $\checkmark$ (2000) Epidemiology of classical swine fever in Germany in the 1990 s. Vet Microbiol 77:29-41

81. Kaden V (1998) The situation of classical swine fever in wild boars in the European community and selected aspects of disease transmission. Berl Munch Tiearztl Wochenschr 111:201-207 (in German)

82. Ribbens S, Dewulf J, Koenen F, Laevens H, de Kruif A (2004) Transmission of classical swine fever. A review. Vet Q 26:146-155

83. Ribbens S, Dewulf J, Koenen F, Maes D, de Kruif A (2007) Evidence of indirect transmission of classical swine fever virus through contacts with people. Vet Rec 160:687-690

84. de Vos CJ, Saatkamp HW, Nielen M, Huirne RBM (2004) Scenario tree modeling to analyze the probability of classical swine fever virus introduction into member states of the European Union. Risk Anal 24:237-253

85. Dewulf J, Laevens H, Koenen F, Mintiens K, de Kruif A (2002) An experimental infection to investigate the indirect transmission of classical swine fever virus by excretions of infected pigs. J Vet Med B Infect Dis Vet Public Health 49:452-456

86. Dewulf J, Laevens H, Koenen F, Mintiens K, De Kruif A (2001) An experimental infection with classical swine fever virus in pregnant sows: transmission of the virus, course of the disease, antibody response and effect on gestation. J Vet Med B Infect Dis Vet Public Health 48:583-591

87. Floegel G, Wehrend A, Depner KR, Fritzemeier J, Waberski D, Moennig $\checkmark$ (2000) Detection of classical swine fever virus in semen of infected boars. Vet Microbiol 77:109-116

88. Hennecken M, Stegeman JA, Elbers ARW, van Nes A, Smak JA, Verheijden JHM (2000) Transmission of classical swine fever virus by artificial insemination during the 1997-1998 epidemic in the Netherlands: a descriptive epidemiological study. Vet Q 22:228-233

89. Elbers ARW, Stegeman A, Moser H, Ekker HM, Smak JA, Pluimers FH (1999) The classical swine fever epidemic 1997-1998 in the Netherlands: descriptive epidemiology. Prev Vet Med 42:157-184

90. Dewulf J, Laevens H, Koenen F, Mintiens K, de Kruif A (2000) Airborne transmission of classical swine fever virus under experimental conditions. Vet Rec 147:735-738

91. Weesendorp E, Backer J, Loeffen W (2014) Quantification of different classical swine fever virus transmission routes within a single compartment. Vet Microbiol 174:353-361

92. Weesendorp E, Stegeman A, Loeffen WLA (2009) Quantification of classical swine fever virus in aerosols originating from pigs infected with strains of high, moderate or low virulence. Vet Microbiol 135:222-230

93. Weesendorp E, Landman WJM, Stegeman A, Loeffen WLA (2008) Detection and quantification of classical swine fever virus in air samples originating from infected pigs and experimentally produced aerosols. Vet Microbiol 127:50-62

94. Weesendorp E, Loeffen W, Stegeman A, de Vos C (2011) Time-dependent infection probability of classical swine fever via excretions and secretions. Prev Vet Med 98:152-164

95. Klinkenberg D, de Bree J, Laevens H, de Jong MCM (2002) Withinand between-pen transmission of Classical Swine Fever Virus: a new method to estimate the basic reproduction ratio from transmission experiments. Epidemiol Infect 128:293-299

96. Laevens H, Koenen F, Deluyker H, de Kruif A (1999) Experimental infection of slaughter pigs with classical swine fever virus: transmission of the virus, course of the disease and antibody response. Vet Rec 145:243-248

97. Laddomada A (2000) Incidence and control of CSF in wild boar in Europe. Vet Microbiol 73:121-130

98. Rossi S, Fromont E, Pontier D, Cruciere C, Hars J, Barrat J, Pacholek X, Artois M (2005) Incidence and persistence of classical swine fever in free-ranging wild boar (Sus scrofa). Epidemiol Infect 133:559-568

99. Zanardi G, Macchi C, Sacchi C, Rutili D (2003) Classical swine fever in wild boar in the Lombardy region of Italy from 1997 to 2002. Vet Rec 152:461-465

100. Stegeman A, Elbers ARW, Bouma A, de Smit H, de Jong MCM (1999) Transmission of classical swine fever virus within herds during the 1997-1998 epidemic in The Netherlands. Prev Vet Med 42:201-218

101. Elbers ARW, Stegeman JA, de Jong MCM (2001) Factors associated with the introduction of classical swine fever virus into pig herds in the central area of the 1997/98 epidemic in the Netherlands. Vet Rec 149:377-382

102. Kaden V, Lange E, Steyer H, Bruer W, Langner CH (2003) Role of birds in transmission of classical swine fever virus. J Vet Med B Infect Dis Vet Public Health 50:357-359

103. Everett $H$, Crooke H, Gurrala R, Dwarka R, Kim J, Botha B, Lubisi A, Pardini A, Gers S, Vosloo W, Drew T (2011) Experimental infection of common warthogs (Phacochoerus africanus) and bushpigs (Potamochoerus larvatus) with classical swine fever virus. I: susceptibility and transmission. Transbound Emerg Dis 58:128-134

104. Weesendorp E, Stegeman A, Loeffen WLA (2008) Survival of classical swine fever virus at various temperatures in faeces and urine derived from experimentally infected pigs. Vet Microbiol 132:249-259

105. Edwards S (2000) Survival and inactivation of classical swine fever virus. Vet Microbiol 73:175-181

106. Wijnker JJ, Depner KR, Berends BR (2008) Inactivation of classical swine fever virus in porcine casing preserved in salt. Int J Food Microbiol 128:411-413 
107. Farez S, Morley RS (1997) Potential animal health hazards of pork and pork products. Rev Sci Tech 16:65-78

108. Botner A, Belsham GJ (2012) Virus survival in slurry: analysis of the stability of foot-and-mouth disease, classical swine fever, bovine viral diarrhoea and swine influenza viruses. Vet Microbiol 157:41-49

109. Terpstra C (1991) Hog cholera: an update of present knowledge. Br Vet J 147:397-406

110. Mur L, Atzeni M, Martinez-Lopez B, Feliziani F, Rolesu S, SanchezVizcaino JM (2016) Thirty-five-year presence of African swine fever in Sardinia: history, evolution and risk factors for disease maintenance. Transbound Emerg Dis 63:e165-e177

111. Sanchez-Vizcaino JM, Mur L, Martinez-Lopez B (2013) African swine fever (ASF): five years around Europe. Vet Microbiol 165:45-50

112. Gavier-Widen D, Gortazar C, Stahl K, Neimanis AS, Rossi S, Segerstad CHA, Kuiken T (2015) African swine fever in wild boar in Europe: a notable challenge. Vet Rec 176:199-200

113. World Organisation for Animal Health (2016) African swine fever, Moldava. https://www.oie.int/wahis_2/public/wahid.php/Reviewreport/ Review?page_refer=MapFullEventReport\&reportid=21095

114. Postel A, Moennig V, Becher P (2013) Classical swine fever in Europethe current situation. Berl Munch Tiearztl Wochenschr 126:468-475

115. World Organisation for Animal Health (2016) Classical swine fever, Latvia. http://www.oie.int/wahis_2/public/wahid.php/Reviewreport/ Review?page_refer=MapEventSummary\&reportid=20006

116. European Commission (2015) ASF Strategy for Eastern Part of the EU. SANTE/7113/2015-Rev 4

117. Commission European (2002) Council directive 2002/60/EC of 27 June 2002 laying down specific provisions for the control of African swine fever and amending Directive 92/119/EEC as regards Teschen disease and African swine fever. Off J Eur Communities L 192:27-46

118. Commission European (2001) Council directive 2001/89/EC of 23 October 2001 on community measures for the control of classical swine fever. Off J Eur Communities L 316:5-35

119. Schulz K, Peyre M, Staubach C, Schauer B, Schulz J, Calba C, Häsler B, Conraths FJ (2017) Surveillance strategies for classical swine fever in wild boar-a comprehensive evaluation study to ensure powerful surveillance. Sci Rep 7:43871

120. Haines FJ, Hofmann MA, King DP, Drew TW, Crooke HR (2013) Development and validation of a multiplex, real-time RT PCR assay for the simultaneous detection of classical and African swine fever viruses. PLoS One 8:e71019

121. Aguero M, Fernandez J, Romero LJ, Zamora MJ, Sanchez C, Belak S, Arias M, Sanchez-Vizcaino JM (2004) A highly sensitive and specific gel-based multiplex RT-PCR assay for the simultaneous and differential diagnosis of African swine fever and classical swine fever in clinical samples. Vet Res 35:551-563

122. Petrov A, Schotte U, Pietschmann J, Drager C, Beer M, AnheyerBehmenburg H, Goller KV, Blome S (2014) Alternative sampling strategies for passive classical and African swine fever surveillance in wild boar. Vet Microbiol 173:360-365

123. Lange M, Kramer-Schadt S, Blome S, Beer M, Thulke HH (2012) Disease severity declines over time after a wild boar population has been affected by classical swine fever-legend or actual epidemiological process? Prev Vet Med 106:185-195

124. Gallardo C, Soler A, Nieto R, Cano C, Pelayo V, Sanchez MA, Pridotkas G, Fernandez-Pinero J, Briones V, Arias M (2015) Experimental infection of domestic pigs with African swine fever virus Lithuania 2014 genotype II field isolate. Transbound Emerg Dis 64:300-304

125. de Carvalho Ferreira HC, Weesendorp E, Elbers ARW, Bouma A, Quak S, Stegeman JA, Loeffen WLA (2012) African swine fever virus excretion patterns in persistently infected animals: a quantitative approach. Vet Microbiol 160:327-340

126. Schulz K, Calba C, Peyre M, Staubach C, Conraths FJ (2016) Hunters' acceptability of the surveillance system and alternative surveillance strategies for classical swine fever in wild boar-a participatory approach. BMC Vet Res 12:187

\section{Submit your next manuscript to BioMed Central and we will help you at every step:}

- We accept pre-submission inquiries

- Our selector tool helps you to find the most relevant journal

- We provide round the clock customer support

- Convenient online submission

- Thorough peer review

- Inclusion in PubMed and all major indexing services

- Maximum visibility for your research

Submit your manuscript at www.biomedcentral.com/submit
() Biomed Central 